\title{
Covid-19 Berdampak Ekonomi Dalam Pendidikan Fisika Dan Islam
}

\author{
RM Aziz ${ }^{1)}$ \\ 1) Universitas Islam Negeri Jakarta \\ Email Korespondensi: $\underline{\text { hshira.dyn@gmail.com }}$
}

\begin{abstract}
Islamic Physics has some relation to Hahslm which is related to theory in daily life and also in the economy. Economics is a social science that studies people's economic problems to create prosperity and prosperity. Corona virus or in its scientific designation referred to as Covid-19 which was present in the midst of society in 2020 really seized the attention. The visible impact not only affects public health, but also affects the country's economy. Even today the world economy is experiencing severe pressure caused by the virus. Covid-19 emerged and gave so much influence in various sectors. One sector that is affected and felt is the economic sector. Therefore, in writing this paper, qualitative, epistemological and quantitative methodologies are derived from journal or book data, numeric data, articles and also rereading economic science with the perspective of Islamic epistemology. Based on the results of the methodology that a country needs adequate and appropriate treatment to stabilize the economy in the Covid-19 pandemic so that prosperity and well-being are created in the community.
\end{abstract}

Keywords: Physics, Islam, Hahslm, Economic, Covid-19.

\begin{abstract}
ABSTRAK
Ilmu Fisika Islam memiliki beberapa kaitannya dengan Hahslm yang mana berkaitan dengan Teori dalam kehidupan sehari-hari dan juga dalam perekonomian. Ekonomi merupakan ilmu pengetahuan sosial yang mempelajari masalah-masalah ekonomi rakyat untuk menciptakan kemakmuran dan kesejahteraan. Virus Corona atau dalam sebutan ilmiahnya disebut sebagai Covid-19 yang hadir ditengah-tengah masyarakat pada tahun 2020 sungguh menyita perhatian. Dampak yang terlihat tidak hanya mempengaruhi kesehatan masyarakat, akan tetapi turut mempengaruhi perekonomian negara. Bahkan saat ini perekonomian dunia mengalami tekanan berat yang diakibatkan oleh virus tersebut. Covid-19 ini muncul dan memberikan begitu banyak pengaruh dalam berbagai sektor. Salah satu sektor yang terdampak dan begitu terasa adalah sektor ekonomi. Maka dari itu, dalam penulisan makalah ini menggunakan metodelogi yang bersifat kualitatif, epistemology dan kuantitatif yaitu berasal dari data jurnal atau buku, data angka (numeric), artikel dan juga membaca ulang ilmu pengetahuan ekonomi dengan kaca mata epistemologi Islam. Berdasarkan hasil metodelogi tersebut bahwa suatu negara membutuhkan penanganan yang cukup dan layak untuk menstabilkan perekonomian dalam pandemic Covid-19 ini agar terciptanya kesejahteraan dan kemaslahatan dimasyarakat.
\end{abstract}

Kata Kunci: Fisika, Islam, HASLM, Ekonomi, Covid-19

PENDAHULUAN

Umat Islam harus benar-benar memikirkan arti penting Fisika atau sains secara umum, dalam rangka membangkitkan kembali semangat keilmuan kaum muslim setelah sekian lama tenggelam, dan berpindah ke Barat. Untuk dapat merebut kembali kejayaan Islam dalam dunia ilmu pengetahuan, maka penguasaan terhadap Fisika merupakan salah satu hal penting yang harus mendapat perhatian dari umat Islam, jika ingin meraih sukses dalam kebangkitan sains ini. Konsep besar ilmu dan agama dapat didefinisikan sebagai integrasi ilmu, secara konsisten akan sesuai dengan bentuk universal maupun teori dalam kehidupan sosial. (Khoiri, Agussuryani, and Hartini 2017)

Al- Qur'an mengambil contoh dari kosmologi, fisika, biologi, ilmu kedokteran dan lainnya sebagai tanda kekuasaan Allah untuk dipikirkan oleh manusia. Tidak kurang dari tujuh ratus lima puluh ayat - sekitar seperdelapan al-Qur'an- yang mendorong orang beriman untuk menelaah alam, merenungkan dan menyelidiki dengan kemampuan akal budinya serta berusaha memperoleh pengetahuan dan pemahaman alamiah sebagai bagian dari hidupnya. Kaum muslim zaman klasik memperoleh ilham dan semangat untuk mengadakan penyelidikan ilmiah di bawah sinar petunjuk al-Qur'an, di samping dorongan lebih lanjut dari karya-karya Yunani dan sampai batas-batas tertentu oleh terjemahan naskah-naskah Hindu dan Persia. Dengan semangat ajaran al-Qur'an, para ilmuwan muslim tampil dengan sangat mengesankan dalam setiap bidang ilmu pengetahuan. (Fakhri 2010)

Monezer Kahf berpendapat bahwa perselisihan tentang alat analisis jarang disaksikan antara dua disiplin ilmu karena logika matematika dan empirisme adalah alat utama yang digunakan dalam fiqh Islam juga. Sementara menjelaskan hubungan timbal balik antara keduanya, Kahf mencatat bahwa, sementara metodologi 
ekonomi Islam bertujuan menemukan cara untuk memahami perilaku manusia, metodologi fiqh berusaha untuk menemukan aturan normatif untuk perilaku ini. Perbedaannya hanya bahwa yang pertama menggunakan campuran pendekatan teoritis dan empiris untuk memahami perilaku agen ekonomi individu sedangkan yang terakhir menggunakan pendekatan analitis untuk mengubah aturan normatif individu. (Kizilkaya Ed 2020)

Sementara Nabi Mohamed dan Imam Ali lebih spesifik dalam mengaitkan kerja keras dan keterlibatan dalam aktivitas ekonomi untuk masyarakat dan perdamaian, para penulis abad pertengahan (mis. Ikhwan-usSafa, Ibn Khaldun) mengartikulasikan pentingnya motivasi dalam pengaturan organisasi. Memang, Ikhwan-usSafa, masyarakat intelektual abad kesepuluh, adalah pelopor dalam menggarisbawahi dimensi spiritual kerja selain memenuhi kewajiban agama. (Ali 2009)

Wabah Covid-19 (sebelumnya 2019-nCoV) disebabkan oleh virus SARS-CoV-2. Wabah ini dipicu pada Desember 2019 di kota Wuhan di provinsi Hubei, Cina. Covid-19 terus menyebar ke seluruh dunia. Awalnya episentrum wabah adalah Cina dengan kasus yang dilaporkan di Tiongkok atau wisatawan dari Tiongkok. Meskipun kasus-kasus yang dilaporkan dari Tiongkok diperkirakan telah mencapai puncaknya dan sekarang sedang turun (WHO 2020), kasus-kasus yang dilaporkan dari negara-negara yang sebelumnya dianggap tahan terhadap wabah tersebut, karena standar dan praktik medis yang lebih kuat, baru-baru ini meningkat. Sementara beberapa negara telah mampu menangani kasus yang dilaporkan secara efektif, tidak pasti di mana dan kapan kasus baru akan muncul. Di tengah risiko kesehatan masyarakat yang signifikan yang ditimbulkan Covid-19 kepada dunia, World Health Organization (WHO) telah menyatakan darurat kesehatan masyarakat yang menjadi perhatian internasional untuk mengoordinasikan tanggapan internasional terhadap penyakit tersebut. Namun, saat ini masih diperdebatkan apakah Covid-19 berpotensi meningkat menjadi pandemi global. (McKibbin and Fernando 2020)

Penelitian ini bertujuan untuk menjawab pertanyaan permasalahan yaitu dengan cara:

- Menganalisis hubungan antara Fisika dan Islam dengan penerapan dalam kehidupan sehari-hari.

- Menganalisis pengaruh Ilmu Pengetahuan Fisika dalam studi empiris dan juga Teoritis mengenai aspekaspek yang mempengaruhi hubungan timbal balik antara Ilmu Pengetahuan Fisika dan Ekonomi.

- Menganalisis Teori Hahslm yang ada dalam kehidupan sehari-hari.

- Menggambarkan penerapan Fisika Islam serta Teori Hahslm yang mempengaruhi perekonmian dalam kasus Covid-19 disuatu Negara.

\section{Landasan Teori Ilmu Fisika Islam}

Penguasaan Fisika diperlukan bukan hanya untuk menghasilkan produk berupa teknologi, akan tetapi juga sangat diperlukan untuk kepentingan ibadah, dan menjalankan kewajiban sebagai seorang hamba yang beriman dan bertakwa kepada Allah SWT. Islam dimaknai sebagai suatu sistem yang holistik, komprehensif atau menyeluruh. (Fakhri 2010)

Grand Unified Theory dan Islam sejatinya berjalan berdampingan yang bermakna bahwa Ilmu dan Islam pasti sesuai dengan fitrah serta nilai universal. Sehingga titik pusat dari puncak peradaban manusia adalah Islam. (Roikhan 2016)

Umat Islam sekarang menghadapi tantangan yang berbeda dan lebih berat daripada zaman dahulu, maka para ilmuan muslim harus bersikap dinamis dan progresif guna merespon tantangan tersebut. Oleh sebab itu, bangunan paradigma yang bersifat radikal, analisi, kritis, universal, dan sistematis juga harus dikuatkan dalam dunia pendidikan khusunya pendidikan Islam. Selain itu ada yang namanya Kesadaran bertauhid berarti kesadaran terhadap wujud sejati yang ada sebagai yang ada, yang oleh Abu Sulaiman dijabarkan dalam Kesatuan (al-wahdaniyah). Merupakan kemestian ideologi aksiomatik yang beraduk semua atom yang ada dalam eksistensi kesadaran nurani dan pemahaman terhadap identitas diri. (Halik 2013)

\section{Landasan Ekonomi dan Covid-19}

Sistem ekonomi adalah cara sebuah negara untuk mengatur jenis produk yang dihasilkan, menghasilkan barang itu dan bagaimana barang tersebut didistribusikan kepada masyarakat. Penentuan sistem ekonomi tidak dapat dilepaskan dari ideologi yang diyakini oleh negara. Ideologi tertentu akan melahirkan sistem ekonomi tertentu pula karena pada dasarnya, negara melalui ideologinya telah memiliki cara pandang tertentu untuk memandang dan menyelesaikan persoalan yang mereka hadapi. Setiap sistem ekonomi membutuhkan sekumpulan peraturan, ideologi yang mendasarinya, menjelaskan peraturan tersebut dan keyakinan individu yang akan membuatnya terus dijalankan. (Hamid 1998)

Menurut Abdel Rahman Yousri Ahmed, ekonomi Islam sebagai gabungan unik antara prinsip syariah dengan ekonomi konvensional. Selagi konsep dan prinsip ekonomi konvensional tidak kontradik dengan prinsip Islam, maka ia boleh diaplikasikan dalam ekonomi Islam. Kita perlu meneroka hubungan ekonomi Islam dengan ekonomi sekular (lazim) dan mengenal pasti elemen-elemen yang boleh diguna pakai dalam membentuk ekonomi Islam. ekonomi Islam adalah gabungan unik antara prinsip syariah yakni undang-undang Islam dan nilai-nilai agama dengan ekonomi lazim. Apabila perkara ini difahami, maka hubungan ekonomi Islam dengan ekonomi sekular dapat dilihat dan dibina secara saintifik dan kukuh. (Auzir 2015)

Diperlukan sinkronisasi antara teori yang berasal dari Al-Quran dengan praktik yang terjadi di dalam simulasi dan teknologi modern, sehingga butuh adanya koridor berupa konsep besar dari ilmu dasar Islam itu 
sendiri. Islam dimaknai sebagai suatu sistem yang holistik, komprehensif, atau menyeluruh. Menyeluruh bermakna semua bagian tanpa terkecuali menjadi bagian dari suatu sistem. Pengembangan epistemologi dalam Ilmu Ekonomi Islam yang Kaffah menghadirkan terminology baru menjadi suatu pendekatan Sinlammim Kaffah. Hal ini sesuai dengan isi al-Quran yang berbunyi 'silmi kâffah', dengan penjelasan bahwa kata 'silmi' merupakan derivasi dari huruf sin lam mim. (Roikhan, 2015)

Selain itu juga, Ekonomi Islam dibangun atas dasar agama Islam, karenanya ia merupakan bagian yang tak terpisahkan dari agama Islam. Sebagai deriviasi dari agama Islam, ekomomi Islam akan mengikuti agama Islam dalam berbagai aspeknya. Islam adalah sistem kehidupan (way of life), dimana Islam telah menyediakan berbagai perangkat aturan yang lengkap bagi kehidupan manusia, termasuk dalam bidang ekonomi. (Nahriyah 2018) Ekonomi Islam ini tidak berarti bahwa kita dapat mengecualikan pengalaman dalam metodologi kita. teori ekonomi islam pada akhirnya harus diverifikasi berdasarkan pengalaman nyata. (Ahmed 2002)

Islamisasi pengetahuan memerlukan tiga langkah utama, yaitu (Anita Rahmawaty 2008):

a. Penguasaan disiplin ilmu-ilmu modern yang diikuti oleh penilaian kritis atas metodologi, temuan ilmiah dan teori yang selaras dengan visi Islam.

b. Penguasaan tradisi ilmiah Islam disertai dengan evaluasi kritis pandangan tentang doktrin-doktrin agama, kebutuhan umat saat ini, dan kemajuan ilmu pengetahuan modern.

c. Sintesis kreatif antara warisan Islam dan pengetahuan modern sebagai lompatan kreatif untuk menjembatani kesenjangan ilmiah yang terjadi selama masa-masa panjang kevakuman pengembangan ilmu pengetahuan Islam.

Skenario hipotetis kasus Covid-19 terburuk untuk perekonomian, menggambarkan dampak ekonomi jika wabah Covid-19 signifikan. Ini tidak boleh ditafsirkan sebagai prediksi bahwa wabah akan terjadi di ekonomi. Sebaliknya, mereka dimaksudkan untuk memandu pembuat kebijakan dalam menentukan seberapa mahal sebuah wabah, sehingga mereka dapat mengevaluasi manfaat dan biaya pencegahan dan respons awal secara tepat. Skenario terburuk ini khusus untuk setiap ekonomi. Mereka berasumsi bahwa jika wabah terjadi dalam ekonomi tertentu, ekonomi itu akan mengalami penurunan besar tetapi sementara dalam pertumbuhan konsumsi, karena perilaku dan kebijakan pencegahan. Ini diasumsikan besarnya guncangan permintaan domestik mungkin pada ujung bawah, terutama untuk ekonomi dengan sistem kesehatan yang lemah. Di negara-negara tersebut, pengendalian dan respons akan lebih sulit, dan wabah yang lebih berkepanjangan bisa terjadi, dengan efek yang lebih besar. Selain itu, biaya jangka panjang melalui saluran lain seperti kesehatan dan pendidikan juga bisa signifikan, dan biaya-biaya itu tidak ditangkap di sini. (Bank 2020)

\section{METODOLOGI}

\section{Ruang Lingkup Penelitian}

Ruang lingkup penelitian ini yaitu menganalisis pengaruh dan juga penerapan dalam Ilmu Fisika Islam serta Teori Hahslm disertai dengan analisis perkembangan perekonomian dan Covid-19 di Indonesia dan bagaimana upaya pemerintah dalam penanganan wabah Covid-19 dan menstabilkan perekonomian yang ada berdasarkan pada Ekonomi Fisika Islam dan Hahslm. Penelitian ini bersifat kualitatif, epistemology dan kuantitatif yaitu baik yang berasal dari data jurnal atau buku, data angka (numeric), artikel dan juga membaca ulang ilmu pengetahuan ekonomi dengan kaca mata epistemologi Islam.

\section{Metode Analisis Epistemology Penelitian}

Pelaku ekonomi adalah mutlak manusia, karena itu dapat disimpulkan bahwa ekonomi adalah sebuah peristiwa antroposentrisme yang dimensi realitasnya terdiri dari dua realitas sirkuler. Dekonstruksi ilmu ekonomi dengan optik epistemology berarti mengkaji ilmu ekenomi secara kritis dengan pendekatan epistemologi Islam. Ilmu ekonomi merupakan sebuah konsep pengetahuan yang memiliki basis epistemology, karena itu pembacaan atas bentuk epsitemologi tersebut memerlukan studi kritis dengan pembacaan ulang berdasarkan kacamata epsitemologi Islam. Pembacaaan epitemologi ekonomi Islam atas ilmu ekonomi merupakan satu alternative dalam rangka membangun kebaikan ilmiah dibidang ilmu ekonomi. Dengan demikian makalah ini akan berusaha membaca ulang ilmu pengetahuan ekonomi dengan kaca mata epistemologi Islam.

Pada realitas pertama manusia adalah peristiwa yang dapat dialami secara general, melalui pencerapan inderawinya sendiri, karena strukturnya terdiri dari komposisi fisika yang terurai. Tetapi realitas pertama ini terbatasi oleh ketentuan-ketentuan tertentu yang berlaku sebagai hukum batasan. Memahami hingga "ilmu" pada obyek dengan realitas fisika ini dibatasi sendiri oleh instrumen fisika manusia. Apa yang dapat diserap manusia pada peristiwa ekonomi pada realitas pertama tersebut, terdiri dari fakta; perilaku, tindakan, rumusan, membangun pendekatan, menyederhanakan fakta ke dalam data, mengkalasifkasi data, mengukur data dan sebagainya. Tetapi tidak akan melampaui karakteristik dari realitas fisika manusia itu sendiri. (Akmal 2013)

Pemahaman terhadap Fisika adalah salah satu usaha untuk melaksanakan perintah Allah yang disyari'atkan di dalam al-Qur'an. Bagaimanapun seseorang tidak boleh lupa bahwa al-Qur'an bukan buku teks sains eksperimental. Jika ia menerangkan beberapa fenomena alam, itu dikarenakan beberapa alasan di bawah ini:

- Studi fenomena alam dan keajaiban-keajaiban penciptaan akan memperkuat keimanan manusia kepada Tuhan. 
- Dengan keakraban terhadap kesempatan-kesempatan yang telah dianugerahkan Tuhan kepada manusia, dia lebih dapat mengenal Allah dan dengan mendapatkan manfaat-manfaat darinya, dia dapat bersyukur kepada-Nya

Dari dua alasan tersebut dapat dipahami bahwasanya Fisika merupakan salah satu jalan bagi manusia untuk menjadi umat yang bertaqwa kepada Allah. Di samping itu Fisika menghindarkan generasi umat Islam dari kebiasaan taklid buta (mengikuti sesuatu tanpa tahu alasannya). Mereka akan memeluk Islam dan berpegang teguh pada keimanan tersebut bukan sebagai agama turun-temurun akan tetapi karena mereka benar-benar menyadari akan kebenaran ajaran-ajarannya, yang telah mereka buktikan sendiri dari pemahaman terhadap alam semesta. (Resmiyanto n.d.)

Contoh tersebut telah menunjukkan akan arti sebuah ilmu pengetahuan tentang gejala-gejala alam (Fisika), karena hal itu berkaitan dengan pondasi keimanan yang kuat dan untuk menjaga generasi (keturunan), diperlukan pendidikan tentang ilmu tersebut. Berdasarkan kejadian tersebut maka adanya Covid-19 ini juga merupakan kejadian yang terbentuk akibat gejala-gejala dari makhluk hidup. Covid-19 ini merupakan gejala makhluk hidup kelelawar dari genus Rhinolophus adalah sumber (reservoir) virus ini dan bahwa musang bulan (Paguma larvata) adalah perantara Sars Cov ke manusia. Satu virus lain, RaTG13, yang ditemukan pada spesies kelelawar Rhinolophus affinis dari Yunan, Tiongkok disebut sangat mirip dengan Sars-Cov-2. Hasil pengurutan genom menunjukkan kesamaan hingga 96 persen antara Sars-Cov-2 dan RaTG13 (Salam 2020). Dengan adanya virus ini yang sudah menjangkit banyak negara membuat beberapa negara kesulitan dalam penangangan Covid19 dan juga kesulitan dalam perekonomian. Dalam makalah ini akan disajikan bagaimana pemerintah Indonesia dalam menangani permasalahan Covid-19 yang akan dibahas melalui data angka (numeric), yang berkaitan dengan perilaku Ekonomi Fisika Islam dan Teori Hahslm dalam kehidupan bermasyarakat.

\section{ANALISIS DAN PEMBAHASAN}

Dalam ekonofisika syariah dapat kita temukan model pada peristiwa teori aliran air yang selalu mencari tempat lebih rendah untuk mengalir. Ilmu fiska tentang air mengajarkan kepada kita, jika tidak ada tempat yang lebih rendah untuk mengalir akan berakibat masalah bagi kehidupan manusia. Masalah ini bisa jadi dalam bentuk bencana banjir. Begitu pula dalam ekonomi Islam, tatkala melihat perputaran harta hanya pada golongan tertentu akan berakibat pada masalah ekonomi, yaitu distribusi kekayaan yang tidak adil. Masalah kesenjangan distribusi ini yang menjadi bahan bahasan utama madzhab Iqtishaduna dalam pemikiran ekonominya. Dalam hal ini, ekonomi Islam memberikan solusinya dengan menggunakan teori zakat untuk mengatasi masalah ketidakadilan dalam distribusi kekayaan. Zakat merupakan rukun islam yang ke-4 dimana wajib hukumnya menunaikan zakat untuk orang yang telah memenuhi nisabnya. (Resmiyanto n.d.)

\section{Islam Kaffoh}

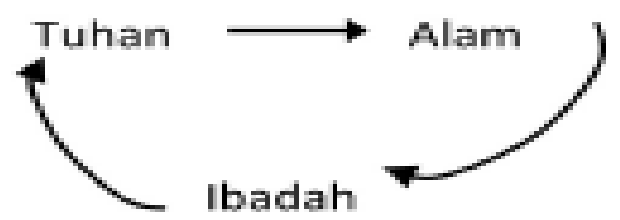

Hubungan ekonomi syariah dan hahslm ini kuat seperti menurut teori yang dikembangkan oleh Roikhan mengenai teori Hahslm Ia mengembangkan epistimology dalam institusi keuangan islam yang kaffah menghadirkan terminologi baru menjadi suatu pendekatan sinlammim kaffah. Hal ini sesuai dengan isi Al-Qur'an yang berbunyi "silmi kaffah" dengan kata "silmi" yang merupakan derivasi dari huruf sin lam mim. (Roikhan 2016) Pendekatan sinlammim kaffah dapat dikembangkan dalam kehidupan seperti pengembangan institusi ekonomi. Dengan merubah elemen pertama(sin), yaitu Tuhan menjadi elemen ekonomi makro, kemudian elemen kedua(lam) adalah alam yang bisa dikonversikan menjadi elemen ekonomi mikro, dan elmen ketiga(mim) yang feedbacknya adalah ibadah yang ditransformasikan menjadi peluang kehidupan berekonom. (Roikhan 2016) 
Perkembangan Covid-19 yang Berdampak pada Perekonomi Nasional Maupun Internasional

Resesi global kini tampaknya tak terhindarkan. Tetapi seberapa dalam dan lama penurunan akan tergantung pada keberhasilan langkah-langkah yang diambil untuk mencegah penyebaran Covid-19, dampak

\begin{tabular}{|c|c|c|c|}
\hline \multicolumn{4}{|c|}{ Table l: COVID-19 statistics (as at 23 ${ }^{\text {rd }}$ April 2020) } \\
\hline Countries & $\begin{array}{c}\text { Confirmed cases } \\
(\text { Total) }\end{array}$ & $\begin{array}{c}\text { Confirmed Deaths } \\
(\text { Total) }\end{array}$ & $\begin{array}{c}\text { Recovered } \\
\text { (Total) }\end{array}$ \\
\hline Global & $2,656,391$ & 185,156 & 729,815 \\
\hline US & 849,092 & 47,681 & 84,050 \\
\hline Italy & 187,327 & 25,085 & 54,543 \\
\hline China & 82,798 & 4,632 & 77,207 \\
\hline Iran & 87,026 & 5,481 & 64,477 \\
\hline Spain & 213,024 & 22,157 & 89,250 \\
\hline Germany & 150,729 & 5,315 & 103,300 \\
\hline UK & 133,495 & 18,000 & - \\
\hline Canada & 40,190 & 1,974 & 13,986 \\
\hline France & 159,877 & 21,340 & 40,657 \\
\hline India & 21,797 & 681 & 4,376 \\
\hline South Korea & 10,702 & 240 & 8,411 \\
\hline Turkey & 98,674 & 2,376 & 16,477 \\
\hline Russia & 62,773 & 555 & 4,891 \\
\hline Brazil & 46,182 & 2,924 & 25,318 \\
\hline South Africa & 3,635 & 65 & 1,055 \\
\hline Nigeria & 873 & 28 & 197 \\
\hline Tunisia & 909 & 38 & 190 \\
\hline $\begin{array}{l}\text { Source: Worldometer }{ }^{5} \text { Note that there may be unconfirmed cases which were never } \\
\text { reported to the public health authorities. }\end{array}$
\end{tabular}

kebijakan pemerintah untuk mengatasi masalah likuiditas di UKM, untuk mendukung keluarga yang berada dalam kesulitan keuangan, dan untuk mengamankan pekerjaan. Itu juga tergantung pada bagaimana perusahaan bereaksi dan berapa lama wabah ini akan berlangsung. Rantai pasokan juga sangat penting. Tidak ada yang dapat secara akurat memprediksi kerusakan finansial final dari Covid-19. Ini jelas tergantung pada waktu, tingkat keparahan pandemi ke minggu / bulan mendatang, dan respons kebijakan negara. Juga, harapan vaksin virus corona meningkat, yang akan menjadi berita baik. Jika krisis yang sedang berlangsung, maka ekonomi tidak hanya ekonomi regional tetapi ekonomi global menghadapi ancaman paling buruk yang terlihat dalam dua abad terakhir. (Fernandes 2020) 


\section{Figure 2 Adverse impact on growth across regions Change in GDP growth in 2020 relative to baseline (percentage points)}

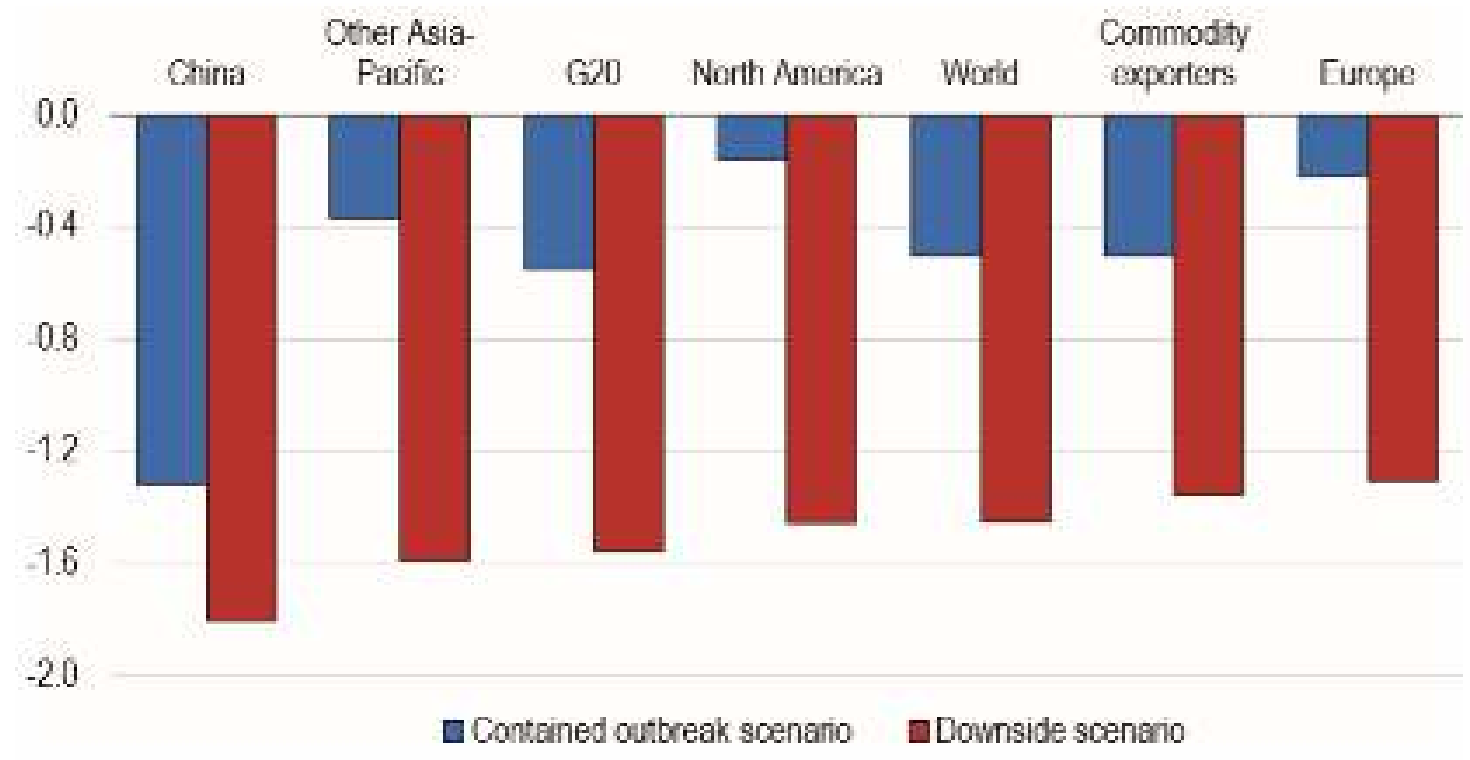

Note: Simulated impact of weaker doanescic demand. lower commodity and equity prices and higher uncettaincy. Coarained outbreak scenamis with the virus outbeak centred in China; downsible scenario with the oubreak spresding significantly in other parts of the Asia-Pacific region, Europe and North America Commodity exporters include Argentina, Brszil, Chile, Rusia, Souch Africa and other non-OECD oil producing economies.

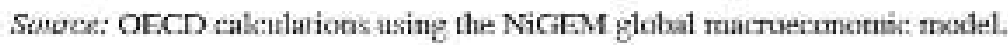

Hal ini menyebabkan kenaikan harga sisa stok pasokan impor yang sudah ada di negara yang bergantung pada impor, yang juga memicu tekanan inflasi pada harga komoditas dasar meskipun permintaan umum rendah untuk impor karena pandemi coronavirus. Sulit untuk menemukan impor alternatif setelah China ditutup karena banyak negara telah menutup sebagian atau sepenuhnya perbatasan mereka yang menghambat perdagangan internasional pada saat itu. (Ozili and Arun 2020)

Dalam hal tersebut, kita tahu bahwa Ilmu ekonomi modern sudah berkembang secara bertahap selama tiga abad terakhir ketika feodalisme menurun dan abad pertengahan berakhir. Sebagai ilmu sosial ia terpisah dari agama pada periode pencerahan selama abad kedelapan belas ketika pikiran manusia membebaskan diri dari takhayul dan dogma agama dan menafsirkan ilmu pengetahuan dan agama, moralitas, politik, hukum, dan ekonomi secara independen dari didikte chruch, dan otoritas agama. sebagai ilmu sosial maka ekonomi menjadi disiplin otonom dan mandiri. (Hoque 1992)

Selain itu juga ILO (International Labour Organization) secara aktif memelihara serangkaian model ekonometrik yang digunakan untuk menghasilkan perkiraan indikator pasar tenaga kerja di negara-negara dan tahun-tahun di mana data yang dilaporkan negara tidak tersedia. Tujuan memperkirakan indikator pasar tenaga kerja untuk negara-negara dengan data yang hilang adalah untuk memperoleh set panel data yang seimbang sehingga setiap tahun, agregat regional dan global dengan cakupan negara yang konsisten dapat dihitung. Ini memungkinkan ILO untuk menganalisis estimasi global dan regional dari indikator pasar tenaga kerja utama dan tren terkait. (ILO 2020) 
Pertumbuhan ekonomi Indonesia pada triwulan I-2020 diperkirakan sebesar 4,7\%. Kemudian pada triwulan II-2020 menurun menjadi 1,1\%. Semua itu berdasarkan proyeksi penyebaran virus corona berlangsung hingga Juni-Juli. Hal tersebut merupakan, skenario berat yang kemudian kita bahas dan sepakati bersama dan menjadi acuan respons apa yang kemudian diperlukan.

Setelah itu, Ia mengungkapkan pertumbuhan ekonomi akan membaik menjadi 1,3\% pada triwulan III-2020 dan 2,4\% pada triwulan IV-2020. Dengan demikian, pertumbuhan PDB sepanjang tahun ini diprediksi 2,3\%. (Iqbal

\section{Skenario Pertumbuhan Ekonomi Indonesia 2020}

\section{Sumber : Komentorian Kouangan (Kemenkou), 6 April 2020}

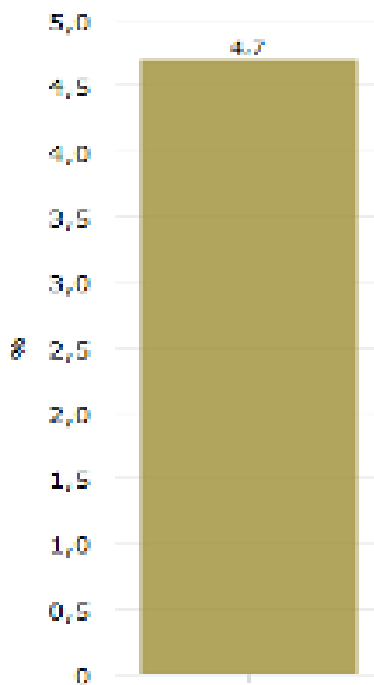

Q1 2020

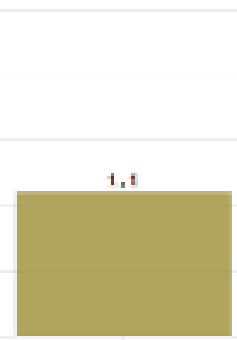

Q2 2020

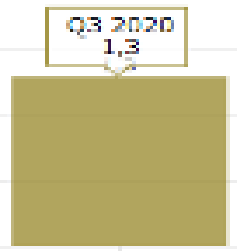

Q3 2020

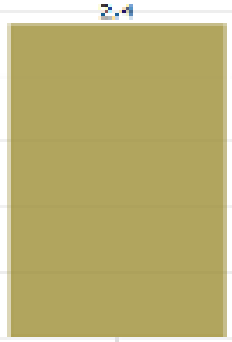

Q4 2020

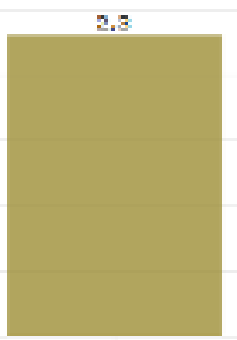

2020

D katadata osid

2020)

\section{Penerapan Ilmu Fisika Islam dan HASLM dalam Perekonomian dan Covid-19}

Dalam kasus Covid-19 yang terjadi di Indonesia dimana pemerintah menerapkan sistem yang sesuai dengan prinsip Fisika Islam serta Teori Hahslm yaitu melakukan hal yang cepat tanggap dalam penanganan Covid-19, memangkas Anggaran Pendapatan dan Belanja Pemerintah yang sebagian dananya di salurkan untuk penanganan Covid-19. Sehingga Uang tersbut mengalir sebagaimana mestinya seperti air yang selalu mengalir ke bawah jika pemerintah menutup mata terhadap kasus Covid-19 ini maka ekonomi akan lesu dan juga perumbuhan penduduk di Indonesia akan menurun yang menyebabkan krisis yang berkepanjangan untuk Negara tersebut. Maka dari itu tidak ada perputaran harta yang hanya ada untuk golongan tertentu yang mana akan berakibat pada masalah ekonomi, yaitu distribusi kekayaan yang tidak adil. Dalam pandemi ini perputaran harta dilakukan secara adil dan dipergunakan dengan sebaik-baiknya. Sehingga masalah kesenjangan distribusi yang menjadi bahan bahasan utama madzhab Iqtishaduna dalam pemikiran ekonominya tidak berlaku dalam pandemic Covid-19 ini. Pemerintah mengalokasikan dana lebih atau dana yang tidak di gunakan dalam Anggran Pemerintah Daerah yang disalurkan untuk penanggulangan kasus Covid-19 demi kesejahteraan dan keselamatan masyarakat.

Anggaran Pendapatan Belanja Daerah (APBD) 34 Provinsi Tahun 2020 Beserta UPDATE Covid-19 DI INDONESIA

\begin{tabular}{|c|l|l|c|c|c|}
\hline No. & \multicolumn{1}{|c|}{ NAMA-NAMA PROVINSI } & \multicolumn{1}{|c|}{$\begin{array}{c}\text { APBD TAHUN } \\
\mathbf{2 0 2 0}\end{array}$} & $\begin{array}{c}\text { TERKONFIR- } \\
\text { MASI }\end{array}$ & SEMBUH & MENINGGAL \\
\hline 1 & Aceh & Rp.17 Triliun & 9 & 4 & 1 \\
\hline 2 & Sumatera Utara (Sumut) & Rp.12,4 Triliun & 111 & 21 & 12 \\
\hline 3 & Sumatera Barat (Sumbar) & Rp.7,3 Triliun & 121 & 23 & 14 \\
\hline 4 & Riau & Rp.12,379 Triliun & 39 & 14 & 4 \\
\hline 5 & Kepulauan Riau (Kepri) & Rp.3,945 Triliun & 86 & 9 & 0 \\
\hline 6 & Jambi & Rp.4,4 Triliun & 32 & 1 & 1 \\
\hline 7 & Bengkulu & Rp.3,3 Triliun & 8 & 1 & \\
\hline 8 & Sumatera Selatan (Sumsel) & Rp.10,6 Triliun & 129 & 18 & \\
\hline 9 & Kepulauan Bangka Belitung & Rp.2,5 Triliun & 10 & 2 & \\
\hline 10 & Lampung & Rp.7,866 Triliun & 42 & 10 & \\
\hline
\end{tabular}




\begin{tabular}{|c|c|c|c|c|c|}
\hline 11 & Banten & Rp.13,214 Triliun & 382 & 33 & 40 \\
\hline 12 & Jawa Barat (Jabar) & Rp.46 Triliun & 912 & 93 & 77 \\
\hline 13 & DKI Jakarta & Rp.87,95 Triliun & 3798 & 335 & 353 \\
\hline 14 & Jawa Tengah (Jateng) & Rp.28,3 Triliun & 666 & 88 & 58 \\
\hline 15 & Yogyakarta & Rp.6,48 Triliun & 83 & 37 & 7 \\
\hline 16 & Jawa Timur (Jatim) & Rp.35 Triliun & 796 & 140 & 88 \\
\hline 17 & Bali & Rp.7,28 triliun & 151 & 10 & 6 \\
\hline 18 & Nusa Tenggara Barat (NTB) & Rp5,6 Triliun & 206 & 22 & 4 \\
\hline 19 & Nusa Tenggara Timur (NTT) & Rp.6 triliun & 1 & 1 & 0 \\
\hline 20 & Kalimantan Utara (Kaltara) & Rp2,85 triliun. & 90 & 2 & 1 \\
\hline 21 & Kalimantan Barat (Kalbar) & Rp.6,3 Triliun & 51 & 7 & 3 \\
\hline 22 & Kalimantan Tengah (Kalteng) & Rp5,339 triliun & 112 & 21 & 12 \\
\hline 23 & Kalimantan Selatan (Kalsel) & Rp.6,9 triliun & 150 & 10 & 6 \\
\hline 24 & Kalimantan Timur (Kaltim) & Rp.11,78 triliun & 107 & 12 & 1 \\
\hline 25 & Gorontalo & Rp. 1,6 triliun & 14 & & 1 \\
\hline 26 & Sulawesi Utara (Sulut) & Rp.4,1 triliun & 40 & 11 & 3 \\
\hline 27 & Sulawesi Barat (Sulbar) & Rp. 2,12 miliar & 35 & 1 & 1 \\
\hline 28 & Sulawesi Tengah (Sulteng) & Rp.1,6 triliun & 36 & 3 & 3 \\
\hline 29 & Sulawesi Selatan (Sulsel) & Rp. 10,6 triliun & 440 & 106 & 40 \\
\hline 30 & Sulawesi Tenggara (Sultra) & Rp. 4,4 triliun & 45 & 6 & 2 \\
\hline 31 & Maluku Utara & Rp. 15,4 triliun & 26 & 2 & 0 \\
\hline 32 & Maluku & Rp. 3,373 triliun & 22 & 11 & 0 \\
\hline 33 & Papua & Rp. 14,6 Triliun & 151 & 32 & 6 \\
\hline 34 & Papua Barat & Rp. 9,3 triliun & 16 & 0 & 1 \\
\hline
\end{tabular}

Terkonfirmasi

« 9.096

+214 kasus
Dalam Perawatan 7.180

$78,93,6 \%$ dari terkonfirmasi

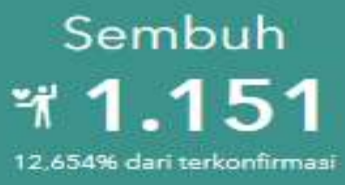

Meninggal

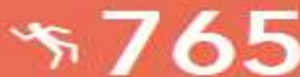

8.419. dariterkonfimas

SUMBER: BERITA APBD 202034 PROVINSI

SUMBER : covid19.go.id UPDATE DATA 26 April 2020, 16:00 WIB

\section{Tren Nasional}

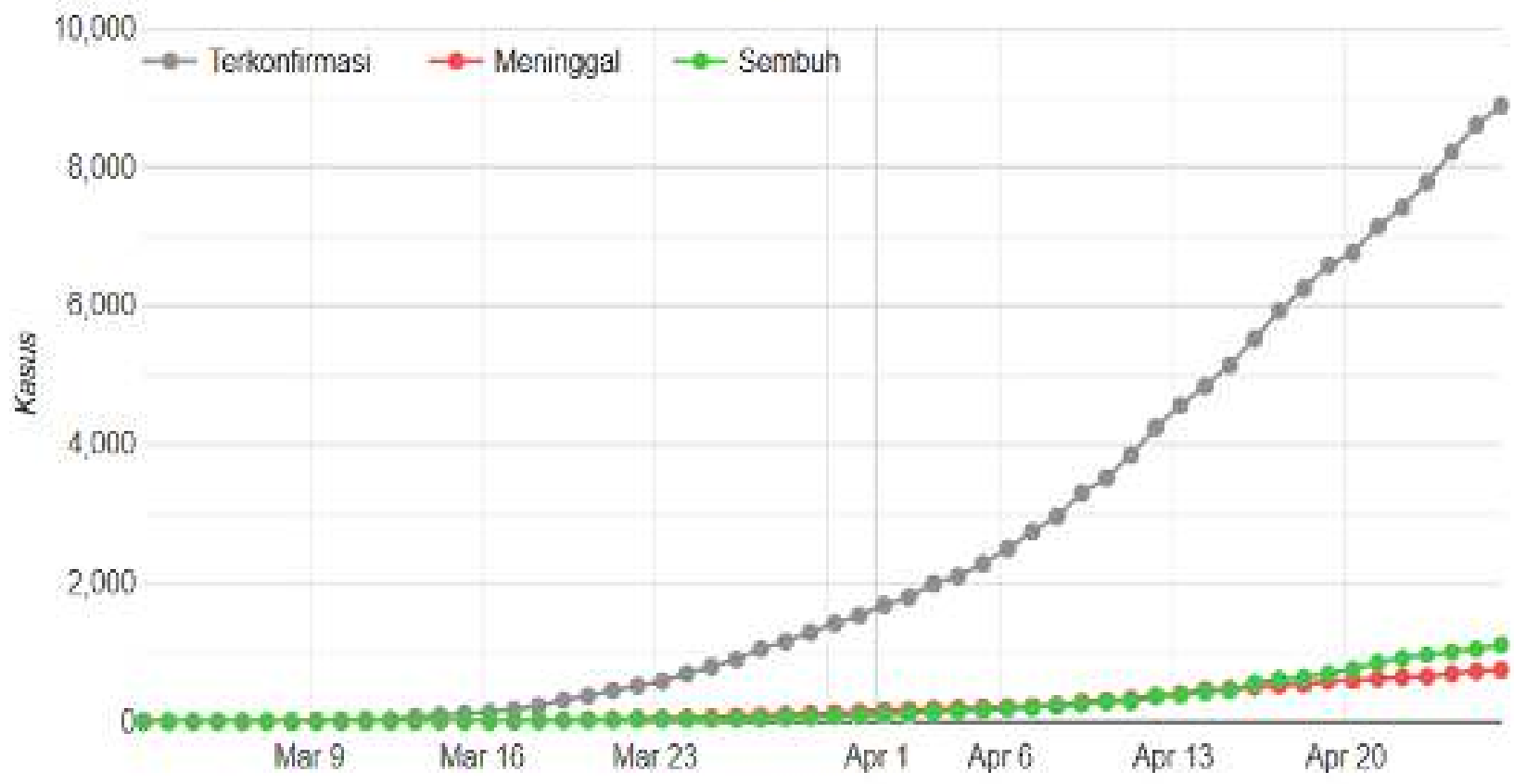

SUMBER : Kompas.com 
Terdapat 26 kasus terkonfirmasi yang masih dalam investigasi di lapangan, oleh karena itu belum terpetakan di atas peta untuk lokasi provinsi kasusnya. Berdasarkan Tren Nasional Covid-19 tersebut, di Indonesia masih meningkat dan belum ada tanda-tanda pengurangan jumlah PDP (covid19.go.id). Selain itu juga, dengan peningkatan Covid-19 yang masih berlangsung pemerintah menerapkan sistem PSBB di beberaapa daearh guna menekan angka Covid-19 makin meningkat.

Jumlah kasus Kasus Covid-19 pertanggal 26 April 2020 di DKI Jakarta yang terkonfirmasi sebesar 3798, Meninggal 335 Jiwa dan sembuh 353 jiwa. Dengan semakin meningkatnya wabah Covid-19 terutama di Ibu Kota Indonesia yaitu DI Jakarta, maka Anggaran APBD 2020 yang di rencanakan untuk pembangunan dan juga kesejahteraan ekonomi di DKI Jakrta sebagain Anggarannya dialihkan untuk penanggulangan Covid-19.

\section{Rincian Anggaran Pendapatan Belanja Daerah (APBD) DKI JAKARTA 2020}

\begin{tabular}{|c|c|c|}
\hline Anжx) run Kryiufan & $44, \times 4 x, 701,569,556$ & \\
\hline Auggaran Non Kegiatau & $31,761,733,118,187$ & Jumlah Belanja Daerah \\
\hline Pembiayaan Pengeluaran & $8,315,713,158,620$ & $\begin{array}{c}\text { Sebesar } \\
79.610 .435 .317 .743\end{array}$ \\
\hline Total APBD & $87,956,118,176,313$ & \\
\hline
\end{tabular}

Deugau Angearan Pendapatan Daerab

\begin{tabular}{|c|c|c|c|}
\hline Peudapatan Asli Daerah & $57,561,162,309,490$ & Jumlah Belanja Daerah & $: 79.610 .135 .317 .743$ \\
\hline Dsans I"crinnbsanyun & $21,618,304,10.52, \times 73$ & Jumlah Pendapatan & $: 82.195 .291 .176 .363$ \\
\hline $\begin{array}{l}\text { I.uin lain Ioneluputan Dastruh } \\
\text { Yang Sah }\end{array}$ & $3,016,52 \mathrm{x}, 114,19 \mathrm{~m}$ & Surplus & $: 2.585 .559 .158 .620$ \\
\hline Jumlah Pendapatan & $82,195,991,176,363$ & & \\
\hline
\end{tabular}

SUMBER ANGGARAN : apbdjakarta.go.id

Pemerintah Provinsi DKI Jakarta bertindak dengan mengalokasikan dana sebesar RP 3,032 Triliun untuk menghadapi pandemic ini.Dana tersebut merupakan tambahan dari alokasi anggaran Belanja Tidak Terduga (BTT). Sejauh ini anggaran BTT DKI Jakarta yang dialokasikan Rp 1,032 Triliun, dan akan ditambahkan sebesar Rp 2 triliun di bulan Mei mendatang. Pengalokasian anggaran ini telah ditandatangani berdasarkan aturan sejak 19 dan 26 Maret 2020. Sehingga anggaran tersebut adalah anggaran rill. Pengalokasian anggaran ini tidak hanya berdasarkan dari anggaran Belanja Tidak Terduga (BTT) saja melainkan juga penundaan sejumlah Penanaman Modal Daerah (PMD) khusunya nggaran infrastruktur pelaksanaan Formula E, dan penundaan pembelian tanah. Sehingga nantinya, dapat dimanfaatkan oleh Dinas Kesehatan, Dinas Sosial, Badan Penanggulangan Bencana Daerah, dan sejumlah Orang Dalam Pengawasan (ODP). (Al Fajri 2020).

Dilansir oleh Republika.co.id. Gubernur DKI Jakarta, Anies Baswedan juga berharap DKI Jakarta mendapat tambahan dana untuk penanganganan COVID - 19. Salah satnya melalui Dana Bagi Hasil (DBH) antara Kementrian Keuangan dan PemProv DKI Jakarta sebesar 7,1 Triliun. Dana Bagi Hasil (DBH) tersebut diperoleh dari piutang KEMENKEU terhadap DKI Jakarta sebesar Rp 6,4 Triliun. Tapi kemudian terdapat beberapa penyesuaian sebesar Rp 5,1 Triliun. Kemudian Dana Bagi Hasil (DBH) di kuartal kedua sebesar Rp 2,4 Triliun. (Indira 2020)

Penerapan Lain mengenai IImu Fisika Islam dan Teori Hahslm dalam Perekonomian dan Covid19 adalah dalam praktek sholat, Dalam anjuran untuk berniat sebelum melakukan sholat maka secara tidak langsung umat manusia juga dianjurkan agar betul-betul menentukan niat yang benar dalam melaksanakan segala aktifitas salah satunya adalah aktifitas ekonomi supaya tercapai apa yang telah dituju dan dimaksud secara benar dan tepat. Bahasa niat dalam hal lain juga bisa dikatakan sebagai penghitungan, pemetaan, proyeksi, strategi, perkiraan, manajemen, dan sebagainya. Begitupun dengan banuan yang diselenggarakan oleh pemerintah setemat, dimana diperlukan perencanaan dan juga stratei agar bantuan tersebit dapat terdistribusi dengan baik. Agar semua masyarakatmendapatkan emaslahatan dalam bantuan tersebut. Bantuan yang dilakukan pemerintah dalam penanganan Covid-19 ini diantara yaitu:

Pertama, Bantuan Tunai Korona (BATUNA). Batuna merupakan bantuan tunai tanpa syarat dalam skenario minimum yang mempertimbangkan aspek-aspek: (i) kemampuan fiskal yang dimiliki oleh pemerintah; (ii) memprioritaskan pemberian bantuan tunaia kepada rumah tangga miskin, rumah tangga kurang mampu dan rumah tangga terdampak pandemi virus korona; (iii) menambal "exclusion error" program perlindungan sosial yang sudah berjalan. (Maftuchan 2020) 


\begin{tabular}{|c|c|}
\hline 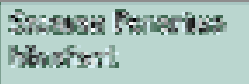 & 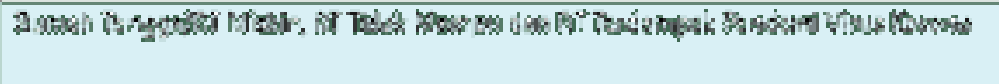 \\
\hline Swaber Lothi & 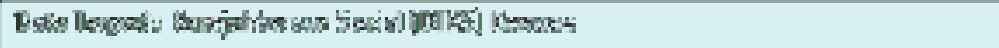 \\
\hline 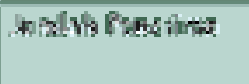 & 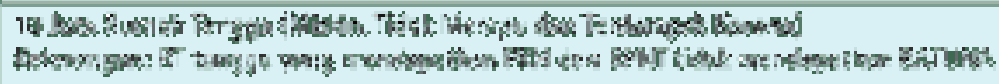 \\
\hline 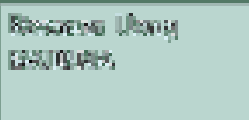 & 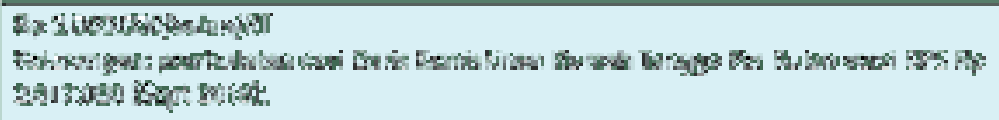 \\
\hline 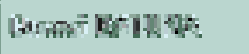 & 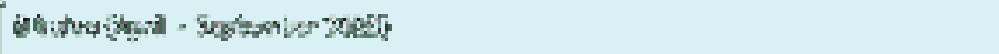 \\
\hline Perockas: & 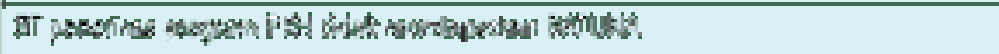 \\
\hline 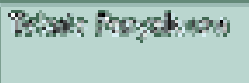 & 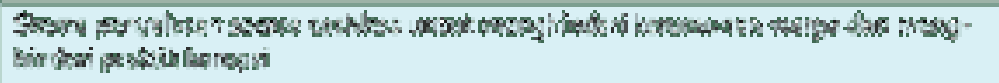 \\
\hline Tulkthase & 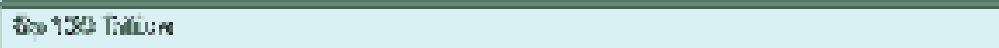 \\
\hline
\end{tabular}

Kedua, Jaminan Penghasilan Semesta (JAMESTA). JAMESTA merupakan bantuan penghasilan dasar tanpa syarat bagi semua warga dalam skenario optimum yang mempertimbangkan aspek-aspek: (i) pengerahan sumber daya fiskal secara optimal untuk perlindungan sosial; (ii) mempercepat dan menyederhanakan proses penyaluran; (iii) mempertimbangkan aspek kecepatan dan ketepatan; (iv) pendekatan semesta di mana semua warga dapat menjadi penerima manfaat; (v) memperkuat relasi sosial dan pemerataan yang berkeadilan; (vi) menghindari "exclusion error" secara total; (vii) menekankan pada pengkonsolidasian dan restrukturisasi alokasi anggaran perlindungan sosial yang sangat beragam (Maftuchan 2020) :

\begin{tabular}{|c|c|}
\hline $\begin{array}{l}\text { Sasaran Penerima } \\
\text { Manfaat }\end{array}$ & $\begin{array}{l}\text { Semua individu: semua usia produktif }(15-64 \text { tahund dan semua usia lanjut usia } 165 \\
\text { tahun }++)\end{array}$ \\
\hline Sumber Data & Survei Penduduk Antar Sensus [SUPAS] 2015 - BPS \\
\hline Jumlah Penerima & Total jum ah penerima. 203 juta jiwo, \\
\hline $\begin{array}{l}\text { Besaran Uang } \\
\text { BATUNA }\end{array}$ & $\begin{array}{l}\text { Rp } 500.000 \text { /bulan/individu } \\
\text { Keterangan pembulatan dan Garis Kemiskinan per kapita per bulan vers Badan Pusat } \\
\text { Statistik As440 } 538 \text { (Sept 2019) }\end{array}$ \\
\hline Durasi BATUNA & 3 bulan (April - Juni 2020) \\
\hline Batasan & Individu usia o tahun - 14 tahun (66 juta jiwa) tidak. mendapatkan JAMKESTA \\
\hline Teknis Penyaluran & $\begin{array}{l}\text { Skema pervaluran secara cashless untuk menghindari kerumunan warga dan meng- } \\
\text { hindari uraxtik korups. }\end{array}$ \\
\hline Total Dana & Ro 304,5 Triliun \\
\hline
\end{tabular}




\section{KESIMPULAN}

Fisika merupakan cabang ilmu pengetahuan alam yang mempelajari gejala-gejala alam dan karakteristik benda-benda fisik. Pemahaman terhadap Fisika merupakan salah satu upaya yang wajib dilaksanakan untuk menanamkan kepercayaan terhadap kekuasaan dan Keagungan Tuhan. Pada prinsipnya, segala sesuatu yang tidak bertentangan dengan maqashid al-syariah al-islamiyah menjadi sesuatu yang dibolehkan dalam ajaran Islam. Di sinilah, letak fleksibelitas Islam dalam merespon perkembangan dan perubahan masyarakat. Islam memungkinkan menyerap ilmu dan pengetahuan yang bersifat positivis setelah melalui proses 'islamisasi' dan 'filterisasi' sehingga pada akhirnya sesuai dengan nilai Islam. Ilmu Fisika Islam dibangun atas dasar agama Islam, karenanya ia merupakan bagian yang tak terpisahkan dari agama Islam. Sebagai deriviasi dari agama Islam, Ilmu Fisika Islam akan mengikuti agama Islam dalam berbagai aspeknya.

Resesi global kini tampaknya tak terhindarkan. Tetapi seberapa dalam dan lama penurunan akan tergantung pada keberhasilan langkah-langkah yang diambil untuk mencegah penyebaran Covid-19, dampak kebijakan pemerintah untuk mengatasi masalah likuiditas di UKM, untuk mendukung keluarga yang berada dalam kesulitan keuangan, dan untuk mengamankan pekerjaan. Itu juga tergantung pada bagaimana perusahaan bereaksi dan berapa lama wabah ini akan berlangsung. Selain itupun ILO juga turut campur dalam penanggulangan Covid-19 karena dengan adanya Covid-19 ini membuat ekonomi global mengalami krisis yang berkepanjangan dan membuat beberapa penyokong pekerja di beberapa negara terganggu.

Dalam kasus Covid-19 yang terjadi di Indonesia dimana pemerintah menerapkan sistem yang sesuai dengan prinsip Fisika Islam serta Teori Hahslm yaitu melakukan hal yang cepat tanggap dalam penanganan Covid-19, memangkas Anggaran Pendapatan dan Belanja Pemerintah yang sebagian dananya di salurkan untuk penanganan Covid-19. Pemerintah mengalokasikan dana lebih atau dana yang tidak di gunakan dalam Anggran Pemerintah Daerah yang disalurkan untuk penanggulangan kasus Covid-19 demi kesejahteraan dan keselamatan masyarakat. Pemerintah mengalokasikan dana sebesar RP 3,032 Triliun untuk menghadapi pandemic ini. Dana tersebut merupakan tambahan dari alokasi anggaran Belanja Tidak Terduga (BTT). Sejauh ini anggaran BTT DKI Jakarta yang dialokasikan Rp 1,032 Triliun, dan akan ditambahkan sebesar Rp 2 triliun. Selain itu juga, penyaluran dana BATUNA dan JAMESTA dikerahkan oleh pemerintah guna penanggulaan Covid-19 di Indonesia untuk masyarakat yang membutuhkan bantuan tersebut untuk melangsungkan kehidupan didalam Pandemic Covid-19 ini. 


\section{DAFTAR PUSTAKA}

Ahmed, Abdel-Rahman Yousri. (2002). Methodelogical Approach to Islamic Economics: Its Philoshopy, Theoritical, Construction and Applicability. 3rd ed. edited by H. Ahmed. King Fand National Library Cataloging.

Akmal, ME. (2013). Dekonstruksi Ilmu Ekonomi Dengan Optik Epistemologi. Jurnal Pemikiran Ekonomi Islam 1(1):1-21.

Ali, Abbas J. (2009). Levels of Existence and Motivation in Islam. Journal of Management History 15(1):50-65.

Anita Rahmawaty, M. A. (2008). Islamisasi Ilmu Ekonomi (Suatu Kajian Metodologi Pengembangan Ekonomi Islam). Ekonomi Islam 1(1):1-28.

Auzir, Mohd Haidzir. (2015). Acuan Ekonomi Islam: Daripada Tasawur Jahiliah Kepada Tasawur Islam. Proceedings ICIEF'15 - Pusat Kajian Pengurusan Pembangunan Islam (ISDEV) Universiti Sains Malaysia (D077-T08P102):894895.

Bank, Asian Development. (2020). The Economic Impact of the Covid-19 Outbreak on Developing Asia. $9(128)$.

Al Fajri, Fitriyadi. (2020). Pemprov DKI Jakarta Gelontorkan Rp. 3 Triliun Tangani Wabah Virus Corona. Tribunnews.Com. Retrieved (https://wartakota.tribunnews.com/2020/04/03/pemprov-dkijakarta-gelontorkan-rp-3-triliun-tangani-wabah-virus-corona).

Indonesia, CNN. (2020). RAPBD DKI Jakarta Disepakati Rp 87,9 Triliun. Retrieved (https://www.cnnindonesia.com/nasional/20191126174318-20-451699/rapbd-dki-jakarta-2020disepakati-rp879-triliun)

Fakhri, Jamal. (2010). Sains Dan Teknologi Dalam Al-Qur'an Dan Implikasinya Dalam Pembelajaran. TA’DIB - Fakultas Tarbiyah IAIN Raden Intan Lampung XV(1):121-42.

Fernandes, Nuno. (2020). Economic Effects of Coronavirus Outbreak (Covid-19) on the World Economy. IESE Business School Spain (1.0):0-29.

Fernando, Warwick McKibbin and Roshen. (2020). Economic In The Time of Covid-19. Editor, Richard Baldwin and Beatrice Weder di Mauro. CEPR Press VoxEU.org eBook. Page 45-51

Halik, Abdul. (2013). Dialektika Filsafat Pendidikan Islam (Argumentasi Dan Epistimologi). ISTIQRA I(1):22-28.

Hamid, Edy Suandy. (1998). Sistem Dan Reformasi Ekonomi Indonesia. Prekonomian Indonesia 1-30.

Hoque, Mohammad Ziaul. (1992). Nature and Methodology of Islamic Economics: An Appraisal. The Pakistan Development Review 31(4):1065-75.

ILO. (2020). Covid-19 and the World of Work: Impact and Policy Responses. (March):1-15. 
Indira, Rediksari. (2020). Menggali Triliunan Dana DKI Jakarta Untuk Covid - 19. Republika.Co.Id. Retrieved (https://republika.co.id/berita/q862yt328/menggali-triliunan-dana-dki-jakarta-untukcovid19).

Iqbal, Muhammad. (2020). Ekonomi RI 2020 Diramal Mentok Hanya 2,57\%. CNBC Indonesia. Retrieved (https://www.cnbcindonesia.com/market/20200410172608-17-151128/ekonomi-ri-2020diramal-mentok-hanya-257).

Khoiri, Ahmad, Qori Agussuryani, and Puji Hartini. (2017). Penumbuhan Karakter Islami Melalui Pembelajaran Fisika Berbasis. 02(1):19-31.

Kizilkaya Ed, Necmettin. (2020). Methodology of Islamic Economics: Problems and Solutions. Turkish Journal of Islamic Economics 7(1):352.

Maftuchan, Ah. (2020). Program Tunai Di Era Covid-19: Bantuan Tunai Korona Atau Jaminan Penghasilan Semesta. Policy Brief (April):1-4.

McKibbin, Warwick J., and Roshen Fernando. (2020). The Global Macroeconomic Impacts of Covid-19: Seven Scenarios. SSRN Electronic Journal.

Nahriyah, Syafa'atun. (2018). Metodologi Dalam Ekonomi Islam. FAI UniversitasMajalengka 1(1):1224.

Ozili, Peterson, and Thankom Arun. (2020). Spillover of Covid-19: Impact on the Global Economy. SSRN Electronic Journal (April).

Resmiyanto, Rachmad. n.d. Ekonofisika, Antara Masa Depan Fisika Dan Ilmu Ekonomi Masa Depan. Pusat Kajian Ekonofisika Indonesia - Blogger.Com. Retrieved (http://ekonofisika.blogspot.com/2009/12/pandangan-islam-terhadap-ekonofisika.html).

Roikhan, M.A. (2015). Rumus Tuhan Hahslm Dalam Berpikir Menyeluruh Sebagai Metodologi Ekonomi Islam. Proceedings ICIEF'15, Mataram - Universitas Islam Negeri (UIN) Syarif Hidayatullah Jakarta (D107-T09P104):1126-28.

Roikhan. (2016). Teori H Sebagai Ilmu Wahyu Dan Turats Dalam Islam. Jurnal Ushuluddin 24(1):10312.

Salam, Muhammad Aminul Khoiris. (2020). Perilaku Produksi Di Tengah Krisis Global Akibat Pandemi Covid-19 Dan Memanfaatkan Media Online. Universitas Muhammadiyah Sidoarjo, Gelam Candi 1-22. 